\title{
IDENTIFIKASI VIBRIO SP PADA GONAD IKAN CAKALANG (Katsuwonus pelamis $L$ )
}

\author{
Hanny W. Mewengkang \\ Staf Pengajar pada Program Studi Teknologi Hasil Perikanan, \\ Fakultas Perikanan dan IImu Kelautan. UNSRAT. Manado 95115.
}

\author{
ABSTRACT \\ Mewengkang, H.W., 2010. Identification of Vibrio on Gonad of \\ Skipjack Tuna (Katsuwonus pelamis L). Jurnal Perikanan dan Kelautan. \\ Vol VI (1): 18-21.
}

\begin{abstract}
This research was conducted to identify the presence of Vibrio sp. at the gonads of fresh and smoked skipjack tuna. The method used in this research is descriptive method with the parameters examined, ie total bacteria, total Vibrio, morphology and biochemical tests.

Results showed that the total value of Vibrio in fresh skipjack tuna gonad highest TVC $1.1 \times 10^{5} / \mathrm{g}$ and the lowest is $2.0 \times 10^{3} \mathrm{TVC} / \mathrm{gr}$. While the smoke skipjack tuna gonad bacterial growth does not occur. The identification results found 43 strains of Vibrio sp., (7 strains), Vibrio fluvialis (2 strains), Vibrio cincinnatiensis (4 strains), Vibrio damsela (2 strains), Vibrio metschnikovii (1 strain) and 27 other strains was not identified.
\end{abstract}

Keywords: Vibrio, Skipjack, Gonad.

\section{PENDAHULUAN}

Ikan cakalang (Katsuwonus pelamis, L) merupakan salah satu hasil perikanan yang menonjol di Sulawesi Utara dibandingkan dengan jenis ikan lainnya yang merupakan komoditi ekspor. Pemasaran ikan ke pasar lokal adalah dalam bentuk ikan segar dan ikan cakalang asap (Timbowo, 1990).

Produk samping ikan cakalang berupa tulang, jantung dan isi perut, dapat dimanfaatkan untuk manusia, makanan ternak dan industri. Sedangkan gonad ikan cakalang hanya dijual segar atau diolah bersama-sama dengan tulang, jantung ikan dan diasapi kemudian dibungkus dengan daun woka. Gonad ikan cakalang segar cepat mengalami pembusukkan karena dalam penanganan tidak diterapkan proses rantai dingin $0-5^{\circ} \mathrm{C}$, sedangkan gonad ikan cakalang asap jika disimpan pada suhu kamar memiliki daya awet hanya 3-4 hari. Untuk itu perlu dilakukan pencegahan terhadap serangan mikroorganisme dan kontaminan lainnya pada produk tersebut. Oleh sebab itu perlu diadakan pengujian secara mikrobiologi, dalam hal ini pengujian terhadap bakteri penyebab penyakit pada manusia diantaranya Vibrio sp.

Vibrio sp. merupakan salah satu bakteri penyebab penyakit pada manusia yang keberadaannya harus dihindari. Makanan yang biasanya dikontaminasi adalah makanan hasil laut yang masih mentah tanpa melalui proses pemasakan terlebih dahulu atau yang tidak diolah dengan sempurna. Selain itu dapat juga melalui kontaminasi selama proses penanganan dan pengolahan (Anonimous, 2001).

Berdasarkan hal tersebut di atas, maka dilakukan penelitian melalui isolasi dan identifikasi Vibrio sp. pada gonad ikan cakalang segar dan gonad ikan cakalang asap, sebagai salah satu upaya memberikan informasi tentang keberadaan Vibrio sp. yang terdapat pada gonad ikan cakalang segar maupun diasap guna menunjang kegiatan sektor perikanan pada umumnya.

Tujuan penelitian ini adalah untuk mengidentifikasi adanya Vibrio sp. pada gonad ikan cakalang segar dan diasap yang diambil dari pasar Pinasungkulan Karombasan Manado. 


\section{METODOLOGI PENELITIAN}

Metode yang digunakan dalam penelitian ini adalah metode deskriptif (Mantjoro dan Manus, 1987). Sampel gonad ikan cakalang segar dan gonad ikan cakalang asap diambil dari pasar Pinasungkulan Karombasan Manado. Kondisi gonad ikan cakalang asap pada saat dibeli dengan menggunakan daun woka sedangkan gonad ikan cakalang segar tidak dikemas. Sampel dianalisa di Laboratorium Mikrobiologi Hasil Perikanan, Fakultas Perikanan dan IImu Kelautan Universitas Sam Ratulangi Manado.

Parameter yang diamati meliputi jumlah total bakteri (Lay, 1994), jumlah total Vibrio sp. (Ijong, 2002), Isolasi dan Identifikasi Vibrio sp. (Cappucino dan Sherman, 1992). Pengujian morfologi meliputi pewarnaan Gram (Lay, 1994) dan Motility (Cappucino dan Sherman, 1992)

\section{HASIL DAN PEMBAHASAN}

\section{Analisa Total Bakteri}

Berdasarkan hasil analisis total bakteri yang diperoleh untuk gonad ikan cakalang segar dan gonad ikan cakalang asap (Tabel 1).

Dapat dilihat bahwa jumlah koloni bakteri pada gonad ikan cakalang segar memiliki nilai sebesar 2,29 × $10^{5} \mathrm{CFU} / \mathrm{gr}$ lebih tinggi dibandingkan dengan nilai gonad ikan cakalang asap yaitu $2,24 \times 10^{5} \mathrm{CFU} / \mathrm{gr}$. Hal ini disebabkan karena penanganan pada gonad ikan cakalang segar tidak higinis yaitu pada saat penjualan, penanganan yang kurang baik sehingga gonad tersebut terkontaminasi dengan lingkungan, juga dapat disebabkan karena gonad yang dikemas tidak secara vakum sehingga tersedia oksigen yang dapat membantu pertumbuhan mikroba, gonad ikan cakalang segar langsung dipajang dan tidak dikemas sehingga mudah terkontaminasi. Kontaminasi juga dapat terjadi melalui tangan pekerja. Menurut Buckle, dkk., (1987), Keracunan bahan pangan yang terkontaminasi oleh bakteri diakibatkan karena higiene yang buruk dari pekerja dan penangan yang tidak bersih. Sebaiknya pekerja menggunakan sarung tangan plastik yang steril. Gonad ikan cakalang asap memiliki jumlah koloni bakteri yang sedikit karena gonad tersebut sudah mengalami proses pengasapan dan pada saat dijual, sudah dikemas dengan menggunakan daun woka.

Berdasarkan persyaratan mutu oleh Standar Nasional Indonesia (SNI 012729-1992) jumlah bakteri maksimum untuk gonad segar maupun asap adalah 5,0 $\mathrm{x}$ $10^{5} \mathrm{CFU} / \mathrm{gr}$, berarti sampel gonad ikan cakalang segar maupun asap masih aman dan layak untuk dikonsumsi.

\section{Total Vibrio sp}

Data hasil analisa Total Vibrio pada sampel gonad ikan cakalang segar dan gonad ikan cakalang asap dapat dilihat pada Tabel 2.

Dari tabel diatas menunjukkan bahwa nilai Presumtive Vibrio tertinggi pada sampel gonad ikan

cakalang segar yaitu $>1,1 \times 10^{5}$ (MPN/100gr) dan nilai Presumtive Vibrio terendah
Tabel 2. Hasil analisa Presumtive Vibrio dan Total Vibrio pada gonad ikan cakalang segar dan diasap.

\begin{tabular}{crrrc}
\hline \multirow{2}{*}{ Sampel } & \multicolumn{2}{c}{$\begin{array}{c}\text { Presumtive Vibrio } \\
\text { (MPN/100gr) }\end{array}$} & \multicolumn{2}{c}{ Total Vibrio (TVC/gr) } \\
\cline { 2 - 5 } & \multicolumn{1}{c}{ Segar } & Asap & Segar & Asap \\
\hline 1 & $>1,1 \times 10^{5}$ & $9,0 \times 10^{2}$ & $2,0 \times 10^{3}$ & - \\
2 & $1,1 \times 10^{5}$ & $2,4 \times 10^{4}$ & $1,1 \times 10^{5}$ & - \\
3 & $>1,1 \times 10^{5}$ & - & $>1,1 \times 10^{5}$ & - \\
\hline
\end{tabular}

Ket: TVC (Total Viable Count) 
pada gonad ikan cakalang segar yaitu $1,1 \times 10^{5}$ (MPN/100gr). Pada gonad ikan cakalang asap, nilai Presumtive Vibrio tertinggi yaitu 2,4 x $10^{4}$ (MPN/100gr), sedangkan nilai Presumtive Vibrio terendah pada gonad ikan cakalang asap yaitu $9,0 \times 10^{2}$ (MPN/100gr). Total Vibrio tertinggi pada sampel gonad ikan cakalang segar adalah $1,1 \times 10^{5}$ (TVC/gr), sedangkan Total Vibrio terendah pada gonad ikan cakalang segar yaitu $2,0 \times 10^{3}$ (TVC/gr). Sedangkan untuk sampel gonad ikan cakalang asap tidak terjadi pertumbuhan Vibrio. Ini berarti nilai Presumtive dan total Vibrio gonad ikan cakalang segar lebih tinggi dari gonad ikan cakalang asap. Hal ini disebabkan karena gonad ikan cakalang asap telah mengalami proses pengasapan dimana pada proses ini Vibrio tidak dapat tumbuh sama sekali. Suhu optimum pertumbuhan Vibrio adalah $37^{\circ} \mathrm{C}$. Pada suhu $5^{\circ} \mathrm{C}$ atau suhu pendinginan, Vibrio memiliki kemampuan untuk tumbuh sehingga penyimpanan pada suhu dingin tidak efektif untuk membunuh Vibrio walaupun pertumbuhannya dapat ditekan. Fardiaz (1983) menyatakan bahwa suhu pertumbuhan Vibrio sp. berkisar antara $5^{0}-44^{\circ} \mathrm{C}$. Pada suhu $50^{\circ} \mathrm{C}$ bakteri ini tidak dapat tumbuh, berarti Vibrio merupakan bakteri yang tidak tahan pada suhu panas.

\begin{tabular}{|c|c|c|}
\hline \multicolumn{3}{|c|}{ Isolasi dan Identifikasi Vibrio sp } \\
\hline \multirow{6}{*}{\begin{tabular}{l}
\multicolumn{2}{c}{ Untuk memastikan } \\
bahwa mikroba yang \\
mengkontaminasi gonad ikan \\
cakalang segar dan gonad ikan \\
cakalang asap yang dijual di \\
pasar Karombasan adalah \\
Vibrio, maka dilakukan isolasi \\
dan identifikasi bakteri \\
tersebut. Untuk menumbuhkan \\
koloni yang diduga sebagai \\
Vibrio digunakan media selektif
\end{tabular}} & \multicolumn{2}{|c|}{$\begin{array}{l}\text { Tabel 3. Karakteristik Koloni Vibrio } \\
\text { pada media TCBS Agar }\end{array}$} \\
\hline & KOLONI & KARAKTERISTIK KOLONI \\
\hline & GS.I.3, GS.I.5, & Kuning, bulat besar, \\
\hline & $\begin{array}{l}\text { GS.I.1, GS.I.7, GS.II.2, } \\
\text { GS.III.1, GS.III.2, GS.III.4 }\end{array}$ & $\begin{array}{l}\text { Kuning, bulat kecil } \\
\text { dan datar }\end{array}$ \\
\hline & $\begin{array}{l}\text { GS.II.1, GS.II.3, GS.II.8, } \\
\text { GS.III.7, GS.III.8, GS.III.9 }\end{array}$ & $\begin{array}{l}\text { Hijau kebiruan, } \\
\text { bulat kecil }\end{array}$ \\
\hline & $\begin{array}{l}\text { GS.II.4, GS.II.5, } \\
\text { GS.III.3, GS.III.5 }\end{array}$ & $\begin{array}{l}\text { Kuning, tak beraturan } \\
\text { dan menyebar }\end{array}$ \\
\hline
\end{tabular}
Thiosulphate Citrate Bile Salt

Sucrose (TCBS) Agar. Pertumbuhan koloni pada media TCBS Agar yang diduga sebagai Vibrio yaitu koloni yang berwarna kuning dan hijau kebiruan. Koloni Vibrio yang tumbuh bebas pada TCBS Agar ini diisolasi ke media Nutrien Agar kemudian digores pada Nutrien Agar miring, dijadikan kultur sediaan untuk pengidentifikasian sifat biokimianya.

Karakteristik dari 20 koloni yang tumbuh pada media TCBS Agar, diperoleh 6 koloni berwarna kuning, berbentuk bulat kecil dan datar. Sebanyak 4 koloni berwarna kuning, bulat agak cembung dan berukuran lebih besar, 6 koloni berwarna hijau kebiruan berukuran kecil dan 4 koloni menyebar. Tabel 3 mendeskripsikan karakteristik pertumbuhan koloni dari 20 koloni dengan sifat biakannya.

Koloni Vibrio cholerae dan Vibrio alginolyticus berwarna kuning karena mampu memfermentasi sukrosa dan menurunkan $\mathrm{pH}$ dari TCBS Agar. Warna TCBS Agar menjadi warna kuning terjadi ketika bakteri tersebut memfermentasi sukrosa menjadi asam. Vibrio parahaemolyticus sangat jarang memfermentasi sukrosa sehingga warna koloni nampak berwarna hijau (Fardiaz, 1983).

Hasil dari karakteristik morfologi dan biokimia dibandingkan dengan Bergey's Manual of Systematic Bacteriology, ternyata dai 43 galur ditemukan Vibrio (7 galur) dan 4 spesies bakteri Vibrio yaitu Vibrio fluvialis (2 galur), Vibrio cincinnatiensis (4 galur), Vibrio damsela (2 galur), Vibrio metschnikovii (1 galur). Ada 27 galur yang tidak teridentifikasi karena tidak memperlihatkan karakteristik Vibrio sp. 


\section{KESIMPULAN}

Nilai total Vibrio pada gonad ikan cakalang segar yang tertinggi adalah $1,1 \mathrm{x}$ $10^{5} \mathrm{TVC} / \mathrm{gr}$ dan terendah adalah $2,0 \times 10^{3} \mathrm{TVC} / \mathrm{gr}$. Sedangkan pada gonad ikan cakalang asap tidak terjadi pertumbuhan bakteri.

Berdasarkan persyaratan mutu oleh Standar Nasional Indonesia jumlah bakteri maksimum untuk gonad segar maupun asap masih aman dan layak untuk dikonsumsi.

Berdasarkan hasil identifikasi yang dilakukan terhadap 43 galur ditemukan Vibrio (7 galur) dan 4 spesies bakteri Vibrio yaitu Vibrio fluvialis (2 galur), Vibrio cincinnatiensis (4 galur), Vibrio damsela (2 galur), Vibrio metschnikovii (1 galur). Ada 27 galur yang tidak teridentifikasi karena tidak memperlihatkan karakteristik Vibrio sp.

\section{DAFTAR PUSTAKA}

Anonimous, 2001, Material Safety Data Sheets, Vibrio parahaemolitycus Publis Healt Agency of Canada.

Buckle, K. A., R. A. Edwards, G. M. Fleet dan Wooton. 1987. IImu Pangan. Penerjemah Hari Purnomo dan Adiono. Ul-Press. Jakarta.

Cappucino, J.G and Sherman, N.M., 1992. Microbiology a Laboratory Manual. Third edition. The Bejamin/cummings. Publishing.

Fardiaz, S., 1983. Keamanan Pangan. Jilid 1 Jurusan IImu dan Teknologi Pangan Fakultas Teknologi Pertanian. Institut Pertanian Bogor.

ljong, F.G., 2002. Penuntun Praktikum Mikrobiologi Pangan Ikani. Laboratorium Mikrobiologi Hasil Perikanan. Fakultas Perikanan dan IImu Kelautan. UNSRAT. Manado.

Lay, B., 1994. Analisis Mikroba di LAboratorium. PT. Raja Grafindo Persada. Jakarta.

Mabtjoro, E dan Manus, O. 1987. Pengantar Kuliah Filsafat Ilmu. Fakultas Perikanan UNSRAT Manado.

Timbowo, S.M., 1990. Identifikasi Bakteri Pada Ikan Cakalang (Katsuwonus pelamis L). Jurnal Fakultas Perikanan dan IImu Kelautan. Vol. 1 No. 2. Hal 155-158. UNSRAT. Manado. 